\title{
Donald Davie and Englishness
}

\author{
Article
}

Accepted Version

Davies, W. (2019) Donald Davie and Englishness. The Review of English Studies, 70 (294). pp. 332-353. ISSN 0034-6551 doi: https://doi.org/10.1093/res/hgy106 Available at https://centaur.reading.ac.uk/85388/

It is advisable to refer to the publisher's version if you intend to cite from the work. See Guidance on citing.

To link to this article DOI: http://dx.doi.org/10.1093/res/hgy106

Publisher: Oxford University Press

All outputs in CentAUR are protected by Intellectual Property Rights law, including copyright law. Copyright and IPR is retained by the creators or other copyright holders. Terms and conditions for use of this material are defined in the End User Agreement.

\section{www.reading.ac.uk/centaur}

\section{CentAUR}

Central Archive at the University of Reading

Reading's research outputs online 


\title{
Donald Davie and Englishness
}

\author{
William Davies
}

\begin{abstract}
This article examines the importance of 'Englishness' as a thematic element in the poetry and criticism of Donald Davie (1922-1995). Beginning with a consideration of Davie's position writing in the aftermath of the Second World War and the decline of the British Empire, the article argues that Davie capitalises on an internationalist sensibility otherwise rejected by many of the post-war writers of the Movement with whom he was initially linked. In so doing, this article traces a tension in Davie's writing between, on the one hand, a resistance to the parochialism and insularity he saw emerging in post-war England, particularly in the poetry of Philip Larkin, and, on the other, the affirmation of a living 'Englishness' that he explores through England's provincial regions and, at times more problematically, the nation's imperial past. This is detailed further through Davie's later poetry, particularly the long poem England and the collection The Shires, in which the relation between landscape and history become increasingly significant for Davie's poetics. By framing Davie in terms of his negotiation of 'Englishness', this article locates Davie as a significant poetic commentator during the turbulent changes that England underwent following the Second World War.
\end{abstract}

Like many of the post-1945 writers identified as the Movement, Donald Davie gave much creative and intellectual energy to questions of England and 'Englishness' in the aftermath of the Second World War. ${ }^{1}$ Exhausted by the devastation of the blitz, the trials of rationing and the collapse of the British Empire, England experienced a radical shift in its economic and political fortunes in the years that followed. As Alistair Davies and Alan Sinfield write, '[i]n 1939, Britain was the world's great imperial power; by 1945, even though the empire remained intact, Britain was an enfeebled state'. ${ }^{2}$ It is a moment which Nigel Alderman argues as having induced a 'crisis' of 'Englishness' that amounted to 'the loss of England, or rather the loss of the British Empire, which required England to define itself in its own terms when previously it could define 'Englishness' in opposition to something else.' ${ }^{3}$ In the years following the end of the war, power shifted fully from the old imperial powers towards the United States and the Soviet Union. Despite the post-war Labour government's drive to address social inequality through welfare reform and to restore national pride through events like the 1951 Festival of Britain, the nation's identity remained embattled as its diminished international role was cemented in events like the humiliation of the Suez crisis in 1956.

It is in this context, in the search for an Englishness 'in its own terms', that Davie discerned the need for a new phase of poetry that could both accompany 'a new movement of spirit in society' ${ }^{4}$ and offset the extent to which 'patriotism and parochialism [had become] one and the same' in an England increasingly anxious about its role as part of Britain and a global community. ${ }^{5}$ While a writer such as Philip Larkin produced a poetics that rests on a melancholic nostalgia for an 'England gone' contraction of experience' into 'Little-Englandism' $(T t C, 123)$ - it has been seldom observed that Davie remained more uniquely concerned with what he saw as a 'tight little island' becoming 'too proud of its tightness and its littleness [...] beyond what events dictated' (TtC, 123). ${ }^{7}$ Though a number of the Movement pursued a poetics that was deeply embedded in this 'tight' image of England, Davie's poetry often imagines nation not by the restrictions of 
borders or boundaries but by the international, the topographical or the spatial as part of lived experience, of 'Geography through the eye'. 8

In this essay, I trace Davie's engagements with England and 'Englishness' across his critical writing and poetry. In part, I develop David Herd's description of Davie as a writer for an England grappling with its 'post-war condition' ${ }^{9}$ However, I also offer a different understanding of Davie and 'Englishness' that disentangles him from the conceptions of national identity otherwise attributed to the Movement, as well as an alternative to Herd's contention that 'from its origin in the 1950s, Davie's criticism is a record of the effort to contain poetic language within the contours of country and nation.' ${ }^{10}$ Davie himself claimed the opposite, stating that he moved away from the values of the central figures of the Movement precisely because 'they fed our national wish to be a tight little island unto ourselves' after the war. ${ }^{11}$ By attending to the multiple ways that Davie explores or critiques the idea of nation beyond this notion of 'containment', I show that Davie's criticism and poetry develop a more expansive view of England and 'Englishness' in the post-war period than has previously been considered, one comprised of a 'cautious but consistent movement towards "freedom" 12 that remains concerned with the trappings of patriotism and the need for political balance after the 'stance[s] impressive and absurd' of the '30s and ' $40 \mathrm{~s}$

('Remembering the Thirties', $C P, 29)$. To begin, I position Davie within the context of his own definitions of 'post-war England' and his engagements with writers through which he articulates various facets of Englishness, namely Philip Larkin, T. S. Eliot and W. H. Auden. I then examine how Davie's poetry approaches England and its regions as an intersection of geographical, historical and imagined spaces. In doing so, this essay considers how a sustained interrogation of England and 'Englishness' develops across the work that Davie produced both from within the nation and, often more importantly, from without.

But what were the anxieties of 'Englishness' that preoccupied Davie and his contemporaries? For many of the writers of the 1950s, Orwell's war-time work is significant here: 'We call our islands by no fewer than six different names', Orwell wrote amid the blitz, 'England, Britain, Great Britain, the British Isles, the United Kingdom and, in very exalted moments, Albion.' ${ }^{13}$ Orwell's instinct to trouble over the very name of 'the islands' as the war raged and the empire continued to strain shows that the conception of nation was no more concrete in the grip of international warfare than in the peace-time that followed. As Herd writes, the issue at the heart of England is that it is essentially 'a geopolitical formation that does not have the status of a nation, but which can sometimes function in discourse as if it does; a country, in other words, which is not identical with a nation state but which has, nonetheless, attracted national sentiment.' ${ }^{14}$ Or, as David Gervais observes, 'England is always a country of the mind.' ${ }^{15}$ While true too of the other nations that make up Britain, England enjoyed, and to an extent still does, a unique position as both the primary mode of 'Britishness' perceived by outsiders and the seat of political and colonial power; as Graham MacPhee and Prem Poddar argue,

to describe the United Kingdom as 'English' may well be a source of discomfort for inhabitants of Scotland, Wales and [...] Northern Ireland, who may object that this confusion reflects the subordination of other national traditions and the unacknowledged and illegitimate predominance of the English within this 'nation of nations'. ${ }^{16}$

This also has implications for 'many members of ethnic minorities' for whom 'the term 'English' retains a racial or ethnic coding.' ${ }^{17}$ MacPhee and Poddar also observe, though, that 'British' can function as the differentiation from 'European' for those who conceive of the continental identity 'as distinct and alien', working to in turn reassert a type of national 
'coding.' ${ }^{18}$ 'England is too problematic now to inspire simple patriotism,' as Gervais puts it. ${ }^{19}$

In the decade following the war, the works of the Movement came to represent a response to this 'problematic' image of England which emerged out of the post-war moment. Presented as a rejection of romantic, modernist and foreign traditions in English poetry, the group were recognised as favouring a writing of more 'definitely English qualities' that is 'down-to-earth, empirical, [and] accessible'. ${ }^{20}$ Zachary Leader suggests that this was fundamentally 'a product of postwar anxiety and exhaustion'. ${ }^{21}$ Yet, the Movement writers were also significant for their various emphases on predominantly lower-middle class and non-metropolitan or regional English backgrounds, representing a purposeful shift in the make-up of the literary and social landscape. As Milton Sarkar writes, '[a] Movement poet is perturbed by social problems. Despite being an artefact, a Movement poem is also a public property concerned with public issues.' 22 For Blake Morrison, class is one of the key factors in what has often been dismissed as a bullish 'provincialism' in texts by Movement writers. ${ }^{23}$

Born in 1922 in Barnsley, Yorkshire, to a Baptist family of a Dissenter heritage in 'the tradition of Oliver Cromwell and John Bunyan' $(T t C, 126)$, Davie recalls his formative years as moments of epiphany that revealed the greater implications of the political, regional and class aspects of his upbringing. Indeed, class is a significant point from which Davie's sense of nation emerges, particularly the economic trajectories of his family:

To be sure they had all 'bettered themselves', and though I don't remember that expression being used in my childhood, plainly the idea behind it was still potent in my parents' generation, and even indeed in my own. How ingrained it is in the English, and how tediously mean-minded, this game of class-distinctions! $(T t C, 126)$

A lifelong conservative like his parents, Davie's politics involved a rejection of extreme positions and any movements that capitalised on class disenfranchisement or authoritarian rhetoric. Morrison sees this as a typical 'Movement politics' that can be characterised as 'distrustful of ideals and fearful of radical change'. ${ }^{24}$ Fundamentally, the Movement represented political positions in which they 'looked up to [those] who laid emphasis on stability, tradition, continuity, whose influence was to encourage not adjustment of society but adjustment to it.' ${ }^{25}$ However, they as much rejected 'radical change' as it did a stable and entrenched intellectual 'Establishment' that was viewed as manipulative, upperclass and insular. Indeed, for Davie, the Movement's lasting value was an 'an important phenomenon for historians of English society and culture, since it represented the first concerted though unplanned invasion of the literary Establishment by the scholarship-boys of the petty bourgeoisie' $(T t C, 136)$. The Movement called for a more democratic literary culture which was closer to what they saw as the societal demands of life outside 'Establishment' spheres of post-war England.

If this social conscience was present in Movement literature generally, though, it was also accompanied by a more problematic rejection of foreign influences. Larkin and Amis were in many ways responsible for this image as they bemoaned a kind of post-war malaise which modernism in particular no longer served: 'nobody wants any more poems on the grander themes for a few years' Amis wrote in 1955, 'but at the same time nobody wants any more poems about philosophers or paintings or novelists or art galleries or mythology or foreign cities or other poems. ${ }^{26}$ Nine years later, Larkin had condensed this to just three words when Ian Hamilton asked 'I wonder if you read much foreign poetry?' 'Foreign poetry?', Larkin replied, 'No!'27

Moving between English, Irish and American universities throughout his working life, Davie by contrast developed an acute awareness of both native and outsider positions 
from which he observed an England he saw as 'not a Utopia at all, but precisely the multifarious reality' of histories and regions 'that our politicians claim to take account of, and to legislate for. ${ }^{28}$ Such political sensitivities are mirrored in Davie's poetry and criticism, in a body of work which consistently attends to the effects and impressions that ideas of place and nation can induce in poetry. With his interest also in the technical possibilities of modernism and its incorporation of the foreign, Davie occupies a position quite different from the 'Englishness' of Larkin and Amis. Even during the mid-1950s heyday of the Movement's popularity as the Movement, Davie dismissed what he called 'the silent conspiracy which now unites all the English poets from Robert Graves down to Philip Larkin, and all the critics, editors, and publishers too, the conspiracy to pretend that Eliot and Pound had never happened.' ${ }^{29}$ For Davie, the confinement of an 'English' tradition of poetry to one lineage from Graves to Larkin neglects the ways in which the Anglo-American modernism of Eliot and Pound was indicative of a healthy exchange between external influences and native practices in English poetics. Indeed, Davie would later write his own rebuttal to the Movement's resistance to innovation and rejection of modernism by claiming they too were as self-conscious and disingenuous as the forbears they repudiated. ${ }^{30}$

Nevertheless, despite his stepping away from the Movement, Davie has remained associated with a parochial agenda very much rooted in this connection with the poets of the 1950s. It is from this context that David Herd suggests that some of Davie's most significant critical works - Purity of Diction in English Verse (1952), Articulate Energy (1955) and Thomas Hardy and British Poetry (1972) - subscribe their author to a poetics (and politics) of rootedness and confinement, of 'curtailment' and 'a sense of limit'. ${ }^{31}$ Herd argues that a text such as Thomas Hardy and British Poetry involves a 'curtailment' of such poets as Auden and J. H Prynne, understanding Davie's focus on the 'topographical' as a limitation that enforces a link between poetry and nation. Davie's reading of Auden's 'In Praise of Limestone', Herd suggests, 'entails an explicit topographical restriction' ${ }^{32}$ when Davie writes that Auden 'contrives, by what is really sleight of hand, to superimpose the landscape of Ischia and even perhaps Greece on the limestone landscapes which [...] were the natural habitation of Auden's imagination from his earliest youth'. ${ }^{33}$ Herd's notion of 'restriction' misses Davie's argument, however. Quite distinct from limit, Auden's poem is not restricted 'back' to his English childhood but expanded so that England might be seen in ancient Ischia and vice versa. It is on this that Davie's vision of England is founded: a notion of scale and relation, rather than limit.

Though Davie's politics can quite rightly be described in terms of 'a sense of limit', his attitude towards the scope of 'English' poetry is not narrow and curtailing but expansive and international. Later in his career, Davie was notably forceful on this matter. Soon after the publication of Thomas Hardy and British Poetry, Davie reviewed Ian Robinson's Chaucer and the English Tradition and was particularly perturbed by the author's claim that

Each national literature is a centre from which to view the rest: I feel at home with Chaucer as I cannot with Dante. If English is one's first language, one naturally takes the greatest kind of poetry to be Shakespeare's - and Dickens's, and D. H. Lawrence's, and Chaucer's [...] I do not see how a great English poet could think Dante greater than Chaucer, except in despair of English. ${ }^{34}$

Davie is quick to admonish what he terms the 'self-congratulating insularity' of Robinson's argument, describing it as an 'ostrich-like [...] culturally nationalist thesis' that is blind not only to Chaucer's own European debts but to 'the notion that Dante and Shakespeare, Cervantes and Tolstoy and Goethe, are voices which speak for mankind, or for the mankind of Europe'. ${ }^{35}$ For Davie, Robinson's study is a worrying indication of a pervasive national 
sentiment, one which he also saw at work in the popularity of Philip Larkin's isolationist image of the nation. From within the limits of his political framework, limits that are elaborated on below, Davie teases out a mode of national identity that offers a striking riposte to such insular melancholy. By resisting the curtailment of 'the English tradition' to a nativist stricture, Davie defies the potential move from cultural nationalism to an exclusionary literary politics and offers an alternative poetic model that accommodates the international sensibilities he sees as vital to a thorough understanding of 'Englishness'.

\section{'If civility is gone': Davie and Post-War England}

The effort to step beyond the established limits of 'English' culture was part of Davie's critical thinking from the beginning of his career, one very much bound up in a 'post-war' status to which he gave sustained attention:

We, those of my generation and older, and whatever our nationality, were phantoms, revenants, the unprovided-for and less than three-dimensional survivors. 'Post-war' [...] to me is meaningful still [and] I have a fervent sense that whatever years I have lived through since 1945 have been in many ways anticlimactic, on borrowed time. $(T t C, 70)$

I suggest that this sense of precarity underlines Davie's early explorations of the relationship between the 'national community' and the moral and political effects of language in English poetry. ${ }^{36}$ In Purity of Diction in English Verse, published in 1952, Davie sought to clarify 'the principles underlying purity of poetic diction in English' in an attempt to prevent poets and poetry from receding 'into a private wilderness' that 'alienate[s] more and more potential readers. ${ }^{37}$ Responding to the work soon after publication, John Wain identified Davie's emphases on diction and an Augustan sense of restraint to be a mode of criticism necessary for a 'period of consolidation' which could also take stock of 'the gains made by Eliot and Pound, Auden and Yeats. ${ }^{38}$ Elaborating on this notion in his Foreword to the 1992 republication, Davie writes that the 'reality' of Purity of Diction 'was post-war', that the underlying impulse was to go 'back to basics', 'a matter of 'picking up the pieces' ' because 'the Second World War had invalidated even those radically diminished principles and sentiments that had survived the war of 1914-18.'39 Though the work now reads as somewhat 'prescriptive and constraining,' as Davie puts it in terms that echo his later rejection of Movement writing, the ambition here is social as well as poetic, that close attention to the workings of poetic language should form part of the 'order' and 'structure' that post-war recovery required, particularly as could be found in poetry of the eighteenth century. The lasting assertion of Purity of Diction is that poet and critic are 'writing in a web of responsibilities [...] to the community' in which traditional verse and a wariness of emotional or poetic excess are neither the sole claims of an insular Larkin and Amis-esque orthodoxy nor poetic elements that require the exclusion of modernist experimentations with foreign influences. ${ }^{40}$ Compelled by the conviction that the poetry of the post-war should, in a fundamentally humanist conception, 'reek of humanity, ${ }^{41}$ Dave identified as much national importance in the 'combination of risk-taking modernism and insistence on traditional syntax, diction and morality' ${ }^{42}$ of Boris Pasternak as in the Augustan poets he champions in Purity of Diction.

Davie also developed his sense of 'Englishness' through the living poetry of England that had, obliquely or otherwise, laid claim to visions of the nation at war. This is no more apparent than in Davie's personal, poetic and professional negotiations of two of the most influential writers on his career: Eliot and Auden. 
In 'Eliot in One Poet's Life', Davie declares the Eliot of Four Quartets to have 'meant more to me than any other writer', citing the poet as the 'master' and 'mentor' to whom he is most indebted. ${ }^{43}$ Davie praises Eliot for his sceptical pursuit of 'good' diction and incorporation of non-native forms into English writing, and for producing a sense that an England defined by its traditions does not necessarily exclude the effects of foreign influences or spiritual reflection. Indeed, it is through this intersection that Eliot, and in turn Davie, understood England's relationship to Europe in the aftermath of the Second World War. 'Every country needs to know the best thought $[\ldots]$ of other countries in order to maintain and develop its own', Eliot remarked in a 1943 speech to the Anglo-Swedish Society. 'The history of European civilization is a history of perpetual cross-fertilisation. ${ }^{44}$

Nevertheless, Eliot's Four Quartets is problematic. For Davie, Eliot's war-time sequence is the articulation of a particular form of national identity that Eliot saw as the only salvation for a nation beset by conflict: England as a manifestation of its religious institutions and history. In Eliot's estimations, an England at war required the formal grace of Anglican liturgy and the awareness of Christianity as the force through which England came into being and through which salvation might be found. ${ }^{45}$ Above all, Davie critiques the narrow image of England that Eliot develops in his religious sensibilities:

features of Eliot's adopted Englishness may not be so obvious to a non-British reader; and in that sentence I have slipped in one of them already - English and British are not the same, and when Eliot welcomes 'regionalism' in Notes Towards a Definition of Culture, this is not going to satisfy people who define themselves as Scottish or Welsh, let alone Irish. [...] there are other ways of tying historic Britain in with European Christendom beside the one that Eliot impatiently or blandly took to be the one right way - through Canterbury and Lambeth. ${ }^{46}$

Davie courts provincialism in order to demonstrate the important distinction between 'English' and the erosive tendencies of Eliot's claims to 'Britishness': 'Eliot's sense of Britain,' Davie writes, 'is offensively metropolitan; and not only of Britain, but of England too - his England is to all intents and purposes London, or at most the Home Counties. ${ }^{47}$ Ultimately, for Davie, Eliot's England is unpalatable not for its geographical limitations, but for the orthodoxy it represents. Eliot's via media - his 'middle way'" ${ }^{8}$ - and his selfconfinement to the spheres of 'establishment' Englishness are suspect exactly because they close down any alternative to the orthodox vision of an Anglican, upper-class England: 'there is every reason to doubt whether Eliot would have joined the Church of England if she had not been the established church. ${ }^{49}$ Dissenting in tone, Davie notes that he does not doubt Eliot's faith but that 'it was the utmost importance to him that he choose what should seem to be not a sect at all but a national norm, its normativity shown in that it was backed by the secular and institutional forces of the nation-state. ${ }^{50}$ If Davie and a number of the Movement generation can be counted as themselves occupying a version of the 'middle way', it was by degrees far more 'middle' than what Davie and others saw as Eliot's alignment with an 'Establishment' version of 'the nation-state' that was very much upper-class and elitist.

In the figure of W. H. Auden, a further kind of crisis in national identity was located by the post-war generation of writers. For John Wain, that which destroyed the prospect of a viable 'Englishness' during and after 1945 was 'not the war, but Auden's renunciation of English nationality. ${ }^{\prime}{ }^{1}$ Yet Davie saw in Auden a registering of 'the quite different climate that was to reign in England after the war [...]. Disillusioned perhaps, disenchanted certainly' $(T t C, 16)$. In these terms, a poem such as Auden's The Age of Anxiety (1948) is as much the expression of a post-war reality of the horrors of nuclear bombs and the Holocaust as it is the specific impacts of the war on English civic life: a reality in which 'everybody is reduced to 
the anxious status of a shady character or a displaced person'. ${ }^{52}$ A post-war condition, as Davie puts it above, of 'phantoms' and 'revenants'.

Auden's later 'The Shield of Achilles' (1955) too raises the question of modernity's chaotic reality with images of warfare and violence that contrast with the idealistic images of healing fountains and affirming flames that ended pre-war poems such as 'In Memory of W. B. Yeats' (1939) or 'September 1, 1939' (1939). However, if Auden's post-war writing is often abstracted from a discernibly 'English' focus, it nevertheless returns to the subject by way of form. Whether it is the Anglo-Saxon alliteration of The Age of Anxiety or the Chaucerian rhyme royal stanzas in 'The Shield of Achilles', a specifically English tradition recurs throughout Auden's post-war writing that keeps the moral claims of the poetry in dialogue with the nation which it obliquely invokes.

Davie's early poems dealing with life in post-war England often produce a similar relationship between form and content. In 'Among Artisan Houses', collected in Brides of Reason (1955), Davie writes from the vantage of his wife's family home overlooking Plymouth. The poem reflects on the city's shift from semi-mythical grandeur as an imperial port to the rebuilding that the naval town was forced to embrace after heavy bombing and the collapse of the empire. As in Auden's 'The Shield of Achilles', Davie uses a variation of rhyme royal to accommodate a reflection on whether history still has value for an England now seemingly confined to 'small civilities' $(C P, 12)$ far less magnificent than what is promised and violently denied by the 'artificial wilderness' of Auden's 'Shield'. ${ }^{53}$ Davie's poem acknowledges the disruption of the war and the shifting notion of England by way of a subtle deviation of a deeply 'English' poetic form (one which Chaucer developed through French influences), rhyming the fifth line with the first and third rather than the second and fourth to leave a distorted version of the expected structure. By merging rhyme royal with the unfurling of a single image that resonates with a global significance (Auden's shield, Davie's ruined port town), Auden and Davie point to where 'native' and traditional forms can be used, altered, imitated and reimagined in the pursuit of a contemporary social expression and moral outlook that is not parochial but international and civic.

For Davie, Plymouth represents not just his personal development - encapsulated by his marriage to his wife, Doreen - but also the loss of significance that the decline of the empire and the impact of the blitz threatened to induce. In his memoir, Davie equates the physical destruction of Europe's coastal cities with the demise of the old imperial powers, describing Plymouth as a city 'blitzed out of existence' $(T t C, 65)$ along with 'the once great sea-ports like Liverpool [...] as imperial in their day as Vienna itself' $(T t C, 71)$. Though at times appearing wistful for England's imperialism, Davie's sentiments are more directed to the change that the empire's collapse induced in how England and 'Englishness' were fashioned as signifiers of national and international identities:

Some English cities [...] are accordingly haunted places for us [the post-war generations], melancholy and moving [...]. Since 1945 the contraction of the onceimperial horizons of the English seems to have meant that for younger people than me, if Plymouth is melancholy at all, its melancholy is merely that of the provinces, something shabbier and fustier, with no historical resonance. $(\mathrm{TtC}, 71)$

Implicitly, there is a contrast here between the provinces and London, between a city Jed Esty describes as 'the preeminent imperial metrople" ${ }^{54}$ and the English port-towns through which the empire was managed practically. The result of the "contraction of the once-imperial horizons of the English' is the loss of a global connectivity for the provinces that is quite apart from the effects this had in the English metropolitan centres. Implicit too is Davie's 
sense that, below the 'melancholy' of the 'shabbier' provinces, there remains a 'historical resonance' in these places that might still be demonstrated.

Throughout 'Among Artisan Houses', the speaker surveys Plymouth and reflects on the changes yet to be fully understood by those living in the post-war moment:

And if civility is gone,

As we assume it is, the moulds

Of commonwealth all broken down,

Then how explain that this still holds,

The strong though cramped and cramping tone

Of mutual respect, that cries

Out of these small civilities? $(C P, 12)$

Implicating the economic fallout of the end of the empire within the larger context of postwar recovery, the poem asks that empire not be 'assume[d]' as the sole source of 'civility' in England and, by further implication, that it not be the sole notion on which a conception of community be founded. The poem finds in the 'small civilities' of Plymouth a possible 'mould' for the concept of 'commonwealth', a term that implies not only the decolonisation of the empire but the 'small[ness]' of provincial 'commonwealth', of public well-being. ${ }^{55}$ The poem proposes a network of relations founded on a 'mutual respect' that may be 'cramped' yet, in a moment of recovery and reconstruction, 'still holds' as a basis for communal meaning and a potential 'historical resonance' beyond the memory of empire.

As the poem progresses, the speaker attempts to further identify a source of stability in the face of great change, locating 'the Plymouth Sound' within a heritage that is 'Traditionally maritime, / And sanctioned by the use of time' $(C P, 12)$. The provincial area is posited as a possible space 'Where continuity is clear/ From Drake to now' $(C P, 12)$ in which the legacy of work - and therefore a community that works together - 'could' constitute an ongoing mode of meaning in an England detached from its imperial history. This tension between continuity and change, one already produced by the alteration of the Chaucerian form, is born out in the last stanza in which the poem toys with the weight of the past upon the present in both poetic and political life:

There is no moral to the scene,

Curious relic from the past.

What has and not what might have been

It serves to show now. And at last,

Shortly, nothing will be seen

By which historians may fix

The moral shape of politics. $(C P, 13)$

The claim that 'there is no moral to the scene' seems at odds with Davie's preoccupation with moral and civic expression throughout his early writing, and even introduces a somewhat troubling disinterestedness in the legacy of colonialism beyond England's borders. Yet this ambiguity serves to implement the poem's claim for the difficult legacy of the empire in England's industrial and coastal regions. The invocation of Drake in the second stanza - hero for the empire, villain for those enslaved or conquered - points to the moral liminality that the poem is evincing, suggesting that history, specifically 'time', has 'sanctioned' the unavoidable and life-giving link between the structures of empire and the economic and social 'shape' of England's port towns. To 'fix' morality to this history is to come down for or against the experiences of those in England's provinces, a move the poem's speaker will 
not make. The poem fails to reach beyond this typically Movement-esque 'middle way', but its preoccupation (rightly or wrongly) is not with the moral question of imperialism so much as with the diminished significance and prospects felt by those living and working in the aftermath of the war and, in turn, the empire. Such ambiguity is less palatable when it comes to the history of colonialism, but it is a suitably fraught position in terms of the bomb-ruined nation's victory in 1945 and England's subsequent decline in fortunes on the international stage.

The question of 'shape' also brings us back to the question of form. By making use of a distinct 'shape' of poetry in the rhyme royal variant, Davie offers some 'small' glimpse of where poetry itself might offer a 'shape of politics' that 'still holds' as both 'civil' and 'moral'. Davie constructs a poem that is ordered and 'built' like the nation going through its own rebuilding, a process which John Wain saw as the imperative behind the return to traditional English poetic forms which occurred in the writing of the 1950s: 'the earliest modern poets had been formbreakers [...]. At such a time when exhaustion and boredom [...] are balanced by guilt and fear [...] it is natural that a poet should feel the impulse to build. ${ }^{56}$ This 'impulse to build' can be seen in Davie's attention to form in 'Among Artisan Houses', evoking Auden's 'Shield of Achilles' and its own exploration of the chaos of modernity. However, the poem steps away from Auden's mode of mythological abstraction, giving 'shape' to the 'small civilities' of what it may mean to experience being 'post-war' in England. Auden's is a poetry that sees humanity at risk of an eternity of violence and horror, a present and future defined by the image of a 'million boots in line' etched into the prophetic shield. ${ }^{57}$ By contrast, Davie's poem feels for the prospect of 'post-war', of aftermath, in the quotidian practices of those experiencing the slow process of rebuilding, particularly the rebuilding of an England of provincial, working-class life that is quite distant from the classical, upper-middle-class realm of what Davie terms in another Brides of Reason poem, 'Remembering the Thirties', as '[a]n idiom too dated, Audenesque' $(C P, 28)$.

The progression from post-imperial 'melancholy' to parochialism is a central issue in Davie's attempts to discern a viable English national identity, one he answers with a distinctly modernist embrace of the foreign. ${ }^{58}$ If Davie's scope of acknowledging the dark underbelly of empire is limited in his published writings, an issue further explored below, his view is always towards the open and international rather than the closed-in and xenophobic. This is particularly true for his assessment of England's regions beyond its metropolitan centres, spaces in which post-war 'melancholy' risks 'nourishing insularity and therefore, outside of London, provincialism' (TtC, 71-2). This concern does not dissipate through Davie's later work but finds different expressions in his accommodation of more experimental forms of poetry and foreign influences, a shift brought about in part by the adoption of a life spent across England, Ireland, Italy, France and America. Davie's relationship to England was one of leaving and returning, an 'Audenesque' émigré life-style that became a crucial aspect to the way that England was approached in his later career.

\section{'An alien poet's eyes': England in Davie's later poetry}

Dividing his time between England and America through most of his professional career, Davie's perspective on England gains a degree of distance not present in the earlier writing. Within this, division itself becomes a vital theme in Davie's work, particularly the ways in which the prospect of 'nation' is articulated as a division between the living reality of a nation and the nation as a product of imagination inflected by historical and social forces. For Davie, 'the real England' revealed itself as the product of imagination once he left Yorkshire: 
how can [my children] understand what it meant to me to move south to Cambridge, and then a year southward again, when I reported to join the Navy at Fareham outside Portsmouth? At last I was securely in manorial England, the only real England - if reality is measured and underwritten $[\ldots]$ by the records of the imagination! $(T t C, 34)$

Davie goes on to identify division as fundamental to this imagined England, describing the nation as being at its most valuable when imagined as a space where 'two cultures [of left and right politics] could still be experienced so vividly' (TtC, 34). Division signifies balance, a sentiment echoed in Davie's later poetry and criticism in numerous forms, whether in the implementation of more experimental poetic techniques or the tempering of provincialism with foreign or emigrant perspectives.

In the long poem England, written during Davie's time in Los Angeles in the mid1960s, the speaker explores what Davie identifies as the blinkeredness of English cultural life during the period for which Larkin is again the marker for national sentiment:

poets such as Philip Larkin [...] embrace a deliberate and in a twisted way heroic insularity. Neither in fact nor in imagination will they leave England, and the England of today not yesterday. Perhaps they themselves do not know whether they refuse to travel in other countries because their own gives them all they need, or because they have entered into a private undertaking to use England as a subject, and they are afraid that if they went elsewhere more attractive subjects might present themselves temptingly. ${ }^{59}$

Though directing his own 'undertaking' with 'England as a subject', Davie's England eschews the Larkin tradition of 'heroic insularity' by invoking the internationalist credentials of Anglo-American modernism in both form and setting, blending Poundian canto and an early-Eliot modular structure as the poem documents a flight between Los Angeles and London during which the speaker is both above and outside the titular nation. ${ }^{60}$ Through the journey, the speaker produces an exacting evaluation of England's self-fashioning, taking the position that the nation in the late ' $50 \mathrm{~s}$ and ' $60 \mathrm{~s}$ had become a pastiche of itself in cultural and political life.

Perspective and modes of looking are central to the poem. Passing over North America and Canada induces in the speaker a topographical approach to England: 'Entranced, my thoughts of you [England] / climb no mountains, enter / no bowels but their track / is always and over / a curve of the earth' $(C P, 228)$. The poem echoes the Eliotic pilgrimage process of Four Quartets: the search for personal, national and spiritual meaning. However, Davie's is a less certain journey towards an England that the poem is unwilling to concede to self-satisfaction or to the affirmation of the nation's past that Eliot's war-time poems explore. The poem also more pointedly counters Eliot's suggestion that 'History is now and England' by punning on 'continental' to highlight a tedious xenophobia at work in English historical nostalgia, that 'The drift of any English / conversation or memoir / is less than continental' $(C P, 218)$. Dwelling on the ways in which England projects itself - through 'conversation' (social and cultural exchange) and 'memoir' (historical fashioning) - the poem laments the nation's inability to make anything more than staged platitudes from the history it so heralds.

Much of England is directed at what Davie calls elsewhere 'the pantomime makebelieve of British public life in the 1960s'. ${ }^{61}$ The theatrical metaphor here runs through the poem, too. England is a poem that stages itself in a canto fashion, an attempt at the dexterous yet precise modernist long poem. There is only partial success in the poem's various digressions, but the sections devoted to Davie's intimate knowledge of eighteenth-century 
literature divulge the text's essential critical position: 'The words of this age are spoken / from and on a stage' $(C P, 224)$. The theatrical motif is further sustained in section four by way of Charles Churchill's The Rosciad, an eighteenth-century satire of English theatre. In so doing, the poem suggests itself as the record of an England characterised as 'superannuated' and broken by a backward facing historical consciousness recycled in the performance of national identity: 'England: a Rosciad / A poem about or for / a superannuated England, sapped and distracted / by vying rhetorics and / impeccably evenly-toned / social comedies' $(C P, 225)$. The poem remonstrates the nation for its domestic theatricality, chastising the England of the period for historical-obsession and the prostitution of an antiquated and inward-facing 'Englishness': 'Napoleon was right: / a nation of purveyors. / Now we purvey ourselves' $(C P, 219)$. The assertion of English heritage which the poem addresses particularly a heritage of military victory, the reference to Napoleon echoing the victory in 1945 - conceals a fraying national identity. The anxieties of rebuilding morph into a more concerted effort to discern viable ways for the nation to continue to conceive itself beyond a narrow nostalgia (be it pastoral, imperial or the war-time nationalism of Eliot's Four Quartets): 'Historical time is not / the dimension of these reproaches / Unkindness is the reproach' $(C P, 218)$.

Though the speaker clarifies that the poem retains a social responsibility - 'this is not a poem about you | but FOR you' $(C P, 219)$ - it nevertheless remains 'above' and distanced from the nation it addresses with the speaker appearing apprehensive, even angry in their return. ${ }^{62}$ However, this distance also offers a counterpoint to the growing fame of Larkin whose own staged and historical England is a wistful, diminished nation bound up in 'Wreath-rubbish in Whitehall', as Larkin puts it in the 1964 poem 'Naturally the Foundation Will Bear Your Expenses'. For Davie, this is a vision of the nation that will not, to use Larkin's phrase, 'grow up'. 'But I outsoar the Thames', declares the speaker of 'Naturally the Foundation'. 63 'Outsoaring the Thames (or the Humber) was what Philip Larkin notoriously would never do', remarks Davie whose England maintains its airborne vantage point throughout, soaring not just over the Thames but the great wildernesses of North America, a landmass contentious but crucial in the contours of English history. ${ }^{64}$ Davie's response is not to just disagree but to out-manoeuvre Larkin in the position from which they speak as national commentators, intervening at the point at which Larkin's poetry was becoming de facto voice of post-war England, a voice of the entrenched insider rather than the expatriate onlooker that Davie provides.

If there is a success in countering Larkin's gloomy outlook with a sharper mode of criticism ('FOR you'), it is on the point of colonial history that we more clearly glimpse the blindspots of Davie's sense of 'Englishness' during the period. A stalwart defender of the necessity of foreign presence in England, multi-lingual literary tastes and innovation through exposure to translation, Davie nevertheless produces a problematic apology for colonial expansion, specifically the colonial act itself. 'Among Artisan Houses' makes use of the ambiguity of its seafaring imagery and evocation of Drake to contend with the effects of social change on both historical resonance and civic living. However, in England, alongside the metaphors of theatre, the central critique of the nation as one that only 'purvey[s]' itself is more problematically demonstrated via the history of colonial exploration. The image of the imperial voyage is found throughout section ' 2 ' of the poem, recounting the exploits of 'Scots on the make', of 'Donald Smith of Forres' and Sir George Simpson, 'the bastard', of the Hudson's Bay Company $(C P, 219)$, and of many others 'who paid, paid with [...] blood' $(C P, 220)$ in these endeavours. Davie's usual drive for poetic clarity falls flat here with the attempt to weave a subtler path. Whose 'blood' is unclear given Hudson's Bay Company's integral part in the geographical, economic and political dominance over the indigenous peoples of North America. The poem acknowledges this history is one of 'Brutal manners' 
$(C P, 223)$, yet there is also the vaguer notion that this 'England' of Davie's conception has wasted its imperial connections, that it is a nation in which 'we drag it all down' $(C P, 223)$. This unavoidably limited recognition of colonial history - particularly of oppression and violence - leaves the poem only a partial success as a critique of English life in the 1960s, particularly given the ongoing decolonisation of the empire and the increasing diversification of England's social make-up through immigration. ${ }^{65}$

In part, we can view Davie's position as one that saw itself (particularly against a figure such as Larkin) as justifiably progressive within a conceptual framework in which a past of exploration stands in as a metaphor for an England connected globally. Against Larkin's 'heroic insularity', Davie conjures a pantheon of exploration from the imperial period. However, though he does not claim each figure as 'heroic', Davie undoubtedly neglects or fails to interrogate the dark history of the global impulses he sees as derived from empire; the poem's closing 'Envoi' celebrates that 'those devil-masks /of goggles and flaps are gone' not because it signifies the end of colonial expansion but because travel is now available to all (or at least all who can afford it): 'Thank god it's second nature / Nowadays to fly' $(C P, 228)$. The poem signals a desire for progress, but it does not register the full implications of the history it evokes. ${ }^{66}$ If Davie's contentions trouble what is acceptable for a postcolonial position today, his call is nevertheless for an England, particularly in the 1960s but also significant now, that is outward facing and enriched by foreign influence, and it is through the metaphors of exploration that Davie mediates this sense of national identity against the public discourse of post-war national self-obsession.

In another poem from the period, 'England, for Ezra Pound' (1965), the speaker responds to Pound's 'Canto LXXX', drawing out the implications of the poem's War of the Roses quatrains and its closing lines, 'seeking in thee / But oblivion, not thy forgiveness, FRANCE. ${ }^{67}$ Below the air-space of England, this companion poem gives an account of Pound's attention to 'the English underground' as he drove with Maurice Hewlett across Salisbury plain: ${ }^{6}$

Aquitaine, England's loss,

Maurice Hewlett drove across

That Christmas. It was Pound

Saw the English underground

Angevin. $(C P, 253)$

The speaker is drawn to the topographical and geographical spaces of England's history, teasing out a reflection on the nation's loss of its imperial status by retracing the tension that Pound's canto also obsesses over: the specific relationship between England and Europe. Pound's poem pivots around a youthful encounter with the Magna Carta and the loss of the Angevin regions by King John, a topic that is also the subject of Davie's article 'Ezra Pound Abandons the English' (1975), in which he elucidates on what the Angevin provinces represent for Pound (and so on his own poem): 'The England that Pound mourns the loss of is, as it had been for him from the first, an integral province of western Europe, sharing a common culture with France and always reaching out, through France, to the shores of the Mediterranean. ${ }^{69}$ More clearly articulated in this poem and article than in a work such as England, Davie's is not so much a recycling of the imperial nostalgia he guards against, both in his reflections on Pound critically or in his own writing, but rather that this notion of retreat and 'shutting-up-shop', that the loss of England's imperial power, 'common from coast to coast [...] Far as the fields of France' ('England for Ezra Pound', CP, 253), should not overwhelm the nation with either the desire to 'boast' of former glories or indulge in historical navel-gazing. The poem compares the cultural climate during the First World War 
that prompted Pound to leave - 'Whose land this is, is there none of these parts / To say, and call him suzerain?' $(C P, 253)$ - with what the poem describes in the post-Second World War period as a 'corporeally pressed / England' that is no longer interested in the European question: 'Where / Now the gold and the vair?' $(C P, 253)$. The corporeal 'shrinking', to use Jed Esty's term, of an England 'pressed' shifts the looming monarchism of the poem to a concern with England's international credentials, developed through Davie's focus on Pound. In so doing, the poem reforms questions of England's diminished imperial presence in the world to timely questions of how England will retain a connection to those 'far' 'fields' of Europe.

The importance of this relationship between geography, history and nation to Davie's poetic imagination of England is again confirmed in The Shires (1974). Likely inspired, or at least emboldened, by the Local Government Act of 1972 (enacted in 1974) which reorganised the local authorities of England's regions, the collection is a series of poetic reflections on each English county in which Davie's vision of England is as much formed by the nation's memories (including his own sometimes quite private recollections) and the changing landscapes as it is a recognition of a living England as much defined by its native structures as by its international connections of history and language.

Many of the poems of The Shires oscillate between the private and the public, between statements of memories and the truths to be discerned from them, contextualised by the historical and geographical contours of the nation's regions. In 'Rutland', for example, the 'joke county' (because it had to defend its county status due to a small population) is remapped to fit not new legislation but the landscape of personal mourning: 'my old / Friend, Bill Partridge. Dead now. Had you noticed? / How heavy that weighs, how wide the narrowest shire!' $(C P, 317)$. At times, these manifest in more caustic images of a 'dead-end England' ('Kent', $C P, 310$ ) still not yet benefitting from the promises of post-war prosperity. In others, the poems return to the process of locating the local within the international, rejecting nostalgic pastoralism. In 'Shropshire', the speaker evokes this by an unsurprising but insubstantial reference in the second stanza to A. E. Housman (who figures more prominently in 'Cambridgeshire') in a poem that springs from the memory of 'my schoolchum Billy Greaves / Who surfaced out of the past two years ago, / Breaking his journey to Fiji off one of his leaves; / He spoke to me by phone from San Francisco' $(C P, 317)$. Despite the county's inevitable tie to the pastoral melancholia of Housman, the poem's location emerges from the recollection of a life and relationship built out of foreign spaces and the relation of space to experience. The poems confirm Davie's émigré-eyes yet also suggests an 'alien' element for all those who attempt to observe what must be experienced; as we are told of Sussex, 'The most poeticized / Of English counties, and / An alien poet's eye, / Mine, there to endorse it' $(C P, 320)$.

If The Shires represents a softening to the narrower aspects of provincial identities, particularly given the provocation of the Local Government Act, the provincial does not subsume the poems into the insularity Davie still resisted. In 'Gloucestershire', for example, the 'Provincialism' of the county, 'a laudable Little England', is placed in a dialogue of 'townscape[s]':

Parochialism therefore,

Though of a Tuscan kind,

Discovers in the practice

Of this one homely art

The measure of civilità. $(C P, 307)$ 
'Civility' and the notion of civic living returns to Davie's poetic vocabulary, drawing his subject away from the English 'kind' of 'parochialism' and into a European context derived from a shared 'Tuscan', Latinate heritage. This does not shield 'Gloucestershire', and by implication all the shires, from the critique of 'Provincialism'. The poem suggests, though, that to be provincial does not mean to be parochial, nor that the 'homely art' of provincial English life is sealed from European networks of history and culture. This notion of shared heritage preoccupies too the final poem, 'Yorkshire', in which the speaker uses distinct groups of traditionally female names to distinguish between the native 'feyness of the North' and the 'Angevin [...] / ladies of Latins [...] / Alix, Kate, Eleanor, Anne' $(C P, 323)$, the folkloric native 'elf-queen' in contrast to the 'mothers of Latin earth' $(C P, 324)$.

'Yorkshire' also responds to the Local Government Act, evoking again the regions given up under the Plantagenet kings to imagine an alternate history in which areas of the West Riding are 'gone from King John to a Frenchman' in order to lament the divisions of the county in $1974(C P, 323)$. Uniting these branches of national identity - of European heritage and of historical echo - under the banner 'Yorkshire', the poem weaves together the co-mingling histories of the region to assert a rejection of artificial borders created through either administrative or parochial impulses. In this, we find Davie's central claim in The Shires: that there exists an Englishness of its own unique history, comprised of its own unique patchwork of regions, which is nevertheless European and, beyond that, global.

Barbara Everett suggests a process of oppositions, of division and balance, is central to the collection as it both plays upon the confinement of county borders and dismisses them as rigid constructions:

Everything in 'The Shires' has a decorous 'English' smallness in this sense, a perfect art of self-containment and throw-away grace and wit, all the effects as tacit as they are taciturn. Indeed, the ironies, silences and negations in Davie's art are clearly conditions of their opposite, as a love of country may dictate a refusal to be mindlessly 'patriotic'. ${ }^{70}$

This 'art of self-containment' is distinct from the insularity that Davie rejected, and the 'curtailment' claimed of Davie by David Herd, since it is offset by the very nature of 'the shires' as they are formulated in Davie's collection: distinct yet connected via private memories that are punctuated with public histories and local geographies often set within wider contexts. Take the loose ballad stanzas of 'Lancashire' which overlay memories of the speaker's father with the flow of the river Ribble:

My father was born in Horton

In Ribblesdale - the highest

Signal-box in England

He'd say, but he was biased.

Though Horton is in Yorkshire,

The Ribble flows to the west.

I have imagined that river

With awful interest $(C P, 310)$

The wry humour of 'Though Horton is in Yorkshire' suggests a playful attitude to the confines of borders that the collection implies. Forgoing the revised mapping of Lancashire enacted in 1972 Act, the poem instead follows the river Ribble's 'course' through the area's history, from the burning of 'the famous Lancashire witches' in 1612 through to the march of 
the ill-fated Bonnie Prince Charlie, the 'Young Chevalier', as he 'Rode hopelessly to Preston' in 1745 . The poem continues on the river's journey, comparing the metropolitan to the supernatural, and in the process lightly mocking regional English folklore, in order to chart the areas and specific cities affected by the 1974 legislation:

Liverpool, Manchester, Salford

I've seen, and felt oppressed;

But Clitheroe's haunted river

I've never put to the test.

The poem ends, however, with the jocular memory of the father that generated the poem 'Should anyone taunt me with this, / The sneer's well merited. / But I pray you, remember my father - / The fault's inherited' $(C P, 310-11)$ - leading back to the intersection of geography and private memory around which the image of the county is constructed.

In locating the debts that the collection has to previous visions of England, David Gervais suggests that The Shires recycles the 'holes and corners' of Thomas Hardy's image of the nation as bereft of cohesive identity, defined instead by its regionality: '[The Shires] is surely a celebration of those 'chinks', a poem for every county but none for London or England as a whole. ${ }^{71}$ While Davie certainly does remain indebted to this Hardyesque vision of England, Gervais perhaps misses the extent to which Davie's concern in The Shires is just as much to explore the patchwork nature of England as it is to elevate such an exploration in a manner that, to return to a Movement buzzword, democratises the process of speaking of England through its regions via private, public or imagined modes. The collection develops Davie's more serious and at times more pointed attack on post-war 'Englishness' in poems such as England. It likewise remains concerned with the latent sense found in early Movement texts that to speak of 'provincial England' is to observe and give voice to a wider spectrum of class and social background when conceiving a national identity, one often managed by the central powers in the nation's capital. Davie produces a series of poems as willing to declare their Englishness as they are to chastise or dismiss the detrimental prospects of limiting England to a history of borders and boundaries, or to the narrow vision of the Englishness that 'London' represents.

The Shires respond to the desire for 'continuity' first identified by Davie in early poems like 'Among Artisan Houses'. In doing so, Davie explores the ongoing possibility of 'Englishness' in the face of the nation's precarious international position during the decades after the Second World War and the attempts to redefine regional identities and histories. It is a response that, rather than creating an imagined Hardy Wessex or Housman Shropshire of nostalgic pastoralism - 'What are those blue remembered hills, / What spires, what farms are those? ${ }^{72}$ - instead weaves history, memory and imagination to reflect an England depicted as a living space, a process that, as Everett writes, 'call[s] into being a real life, a real place all the more "warmly exact" for its scrupulous turning-away'. ${ }^{73}$ The Shires also serves to counter the pessimistic estimations of poets such as Larkin in a poem like 'Going Going', in which the speaker is resigned to the degradation of the Hardy/Housman England to a landscape of 'concrete and tyres'. ${ }^{74}$ Davie's own vision of the nation remains resilient to the fact that neither the arrival of concrete amongst woodland nor the disappearance of ancient spaces spells the end of England as a viable if still problematic prospect. Crucially, it also does not entail a retreat from European and international contexts.

\section{Conclusion}


In a probing moment of reflection on his youth in These the Companions, Davie comments on witnessing the first photographs and reports of the concentration camps in Europe: 'I and my school-mates, [were] in entire innocence of the age-old sore [of anti-Semitism] that just then, in the 1930s, was swelling and festering afresh, to be monstrously lanced in Germany by Hitler's 'final solution', $(T t C, 15)$. From this, Davie discerns among 'English people' a common belief in an 'enlightened and knowledgeable, even sceptical' national character that perniciously allowed revelations of the Holocaust to be dismissed or disbelieved: 'I am overcome with simple sorrow for the innocence we all had [before the war] - an innocence that is still to be found in one or two English people I know, for which alas there is nowadays no excuse' $(T t C, 15)$. For Davie, this 'innocence' produced a 'reasonableness' which could result in not just disbelief but full denial of atrocities 'outside' of the national scope. This 'reasonableness' Davie writes, was 'played out over a foundation of unexamined certainties not least the certainty that one could be proud of being British, since the British Empire had been and still was the most enlightened and enlightening of all empires that the world had seen. This showed how provincial we were' $(T t C, 16)$. In this, we see Davie's estimation of the impact of the war and the collapse of the empire on England: the shattering of an illusion that the empire had signified, and been a source of, 'enlightenment'. That he locates this within the provincial context shows that Davie continued to remain wary of uncritical assertions of national identities which might emerge from disconnected communities. The shift in The Shires to an accommodation of the provincial remains one that makes 'no excuse' for insularity or naivety, for a slide from provincialism to parochialism.

Unavoidably, Davie fails to trouble fully the complex history of English imperialism. The identification of the empire as 'a foundation of unexamined certainties' remains itself underexamined in his work. Davie's metaphors of seafaring and the apparent connections of Latinate languages strain under this aspect of his politics, particularly as they are often situated at the point of ambiguity when it comes to the moral legacy of imperial expansion. Nevertheless, Davie resists native entrenchment and exclusionary patriotism, mourning for a nation he identifies as adrift and in need of new meaning; a nation that had moved in its foundations with 'the loss of real or seeming certainties' $(T t C, 16)$ and the loss of 'a global scope for the [English] imagination' that the empire had brought about in Davie's estimations. ${ }^{75}$ Such a sentiment became conviction in Davie's poetics and critical thought as he attempted throughout his writing career to explore forms and traditions defined by clear diction and structure, and to find images of nation and nationhood that could appropriately express the discordant nature of post-1945 England beyond the strictures of Movement 'smallness' and recover some positive, 'civil' sense of national identity in the post-war, postimperial moment.

Revising the contention by Orwell that England is neither the 'jewelled isle of Shakespeare' or the 'inferno depicted by Dr Goebbels' but a 'rather stuffy Victorian family', ${ }^{76}$ Davie asserts a multiplicity of nation that England and The Shires poems elsewhere demonstrate, an image of the nation as at once comprised of 'the England of Shakespeare,' the 'Romish England of Alexander Pope', the 'Anglican England of Jonathan Swift', the 'would-be republican England of Walter Savage Landor' and the 'monarchical England of Alfred Tennyson. ${ }^{77}$ This attention to multiplicity - to the relationship between division and balance - comprises the 'certainties' that Davie longed for, imbuing his sense of England with an acknowledgement that certainty does not necessarily comprise a narrowing of the scope by which the nation is to be conceived, that 'so various Englands exist' in history and the present moment, not as a 'utopia' but as a 'multifarious reality' of 'small civilities'. These 'Englands' in many ways haunt Davie's works, yet they are emphatically multiple in nature, functioning as spaces in which Davie explores the poetic, political, social and historical intersections that nation and nationality represent. 


\section{Notes}

${ }^{1}$ Born out of D. J. Enright's Poets of the 1950s (1955) and Robert Conquest's New Lines anthology (1956), the Movement - Davie, Philip Larkin, Kingsley Amis, John Wain, Elizabeth Jennings, among others - were seen as representing a dominant mode of post-war English writing. For a full discussion of the Movement's formation, see Blake Morrison's The Movement: English Poetry and Fiction of the 1950s (London, 1986).

${ }^{2}$ Alistair Davies and Alan Sinfield (eds.), British Culture of the Postwar (London, 2000), 1.

${ }^{3}$ Nigel Alderman, "The life with a hole in it': Philip Larkin and the Condition of England', Textual Practice, 8:2 (1994), 279-301, 285.

${ }^{4}$ Donald Davie, 'Towards a New Poetic Diction', Prospect, 2 (1949), 5.

${ }^{5}$ Davie, These the Companions (Cambridge, 1982), 123 [hereafter $T t C$; all references to this source are given in the body of the text].

${ }^{6}$ Philip Larkin, 'Going Going', Collected Poems, ed. Anthony Thwaite (London, 2003), 134.

${ }^{7}$ An earlier moment of renegotiation for what 'England' meant for cultural and literary production is identified by Jed Esty as occurring in the 'late modernist' phase of the 1930s in which the 'contraction of the British state' meant that 'England' became a space that modernism could express in literary terms: 'If expansion had exacerbated (or simply symbolized) the fundamental unknowability of English society as a totality, then contraction mitigated (or was taken symbolically to repair) that unknowability'. See A Shrinking Island: Modernism and National Culture in England (Princeton, 2004), 47. Alongside Esty, Marina MacKay has documented the shifts that occurred in modernist thinking around and during the Second World War, particularly in Modernism and World War Two (Cambridge, 2007). Complementing MacKay's focus on prose and fiction, Raphaël Ingelbien's Misreading England: Poetry and Nationhood Since the Second World War (Amsterdam, 2002) complicates the focus on modernism by attending to the post-war work of Heaney, Larkin, Hughes and Hill. For a longer view on the relation between Englishness and poetry, see John Lucas's England and Englishness (London, 1990) which examines eighteenth and nineteenth century attentions to national identity, and David Gervais's Literary Englands: Versions of 'Englishness' in Modern Writing (Cambridge, 1993) which surveys the twentieth century.

${ }^{8}$ England, Collected Poems, ed. Neil Powell (Manchester, 2002), 228 [hereafter CP; all references to this source are given in the body of the text] https://www.carcanet.co.uk/cgibin/indexer?product $=9781857544060$.

9 David Herd, 'Dislocating Country: Post-War English Poetry and the Politics of Movement', in Peter Robinson (ed.) The Oxford Handbook of Contemporary British and Irish Poetry (Oxford, 2013), 497-516.

${ }^{10}$ Herd, 'Dislocating Country', 501.

${ }^{11}$ Qtd. in Sarah Lyall's 'Donald Davie, 73, Poet and Literary Critic, Dies', The New York Times, 1995, <http://www.nytimes.com/1995/09/23/obituaries/donald-davie-73-poet-andliterary-critic-dies.html> accessed: 4 February 2018.

${ }^{12}$ Qtd. in Michael Edwards, 'Donald Davie and British Poetry', Poetry Nation, 3 (1974) <http://www.pnreview.co.uk/cgi-bin/scribe?item_id=4127> accessed 4 February 2018.

${ }^{13}$ George Orwell, The Lion and the Unicorn (London, 1982), 47.

${ }^{14}$ Herd, 'Dislocating Country', 497. 
15 Gervais, Literary Englands, 15.

${ }^{16}$ MacPhee and Poddar (eds.), 'Introduction: Nationalism Beyond the Nation State', Empire and After: Englishness in Postcolonial Perspective (Oxford, 2007), 2.

${ }^{17}$ MacPhee and Poddar, 'Introduction', 15.

${ }^{18}$ MacPhee and Poddar, 'Introduction', 15.

${ }^{19}$ Gervais, Literary Englands, xiii.

${ }^{20}$ Ingelbien, Misreading England, 13. For a discussion of the distinction between 'Englishness' and 'British' in Larkin, Amis and Wain's work, see Leader's 'Movement Fiction and Englishness', Cambridge Quarterly, 42 (2013), 248-51.

${ }^{21}$ Leader (ed.), 'Introduction: Origins and Ambivalences', The Movement Reconsidered (Oxford, 2009), 13.

${ }^{22}$ Milton Sarkar, Englishness and Post-Imperial Space: The Poetry of Philip Larkin and Ted Hughes (Newcastle, 2016), 27.

${ }^{23}$ Morrison, The Movement, 61-3.

${ }^{24}$ Morrison, The Movement, 8. For an extended discussion of Davie's particular form of conservatism, see Robert Von Hallberg's 'Donald Davie and 'The Moral Shape of Politics', Critical Inquiry, 8:3 (1982), 415-36.

${ }^{25}$ Morrison, The Movement, 81.

${ }^{26}$ Amis qtd. in Salem K. Hassan, Philip Larkin and his Contemporaries: An Air of Authenticity (Basingstoke, 1988), 157. Morrison argues for seeing this attack on 'foreign cities' to be as much to do with class as it is a native/foreign binary (The Movement, 61).

${ }^{27}$ Ian Hamilton, 'Four Conversations', London Magazine, 4 (1964); collected in Philip Larkin, Further Requirements: Interviews, Broadcasts, Statements and Book Reviews, ed. Anthony Thwaite (London, 2001), 25 [emphasis retained].

${ }^{28}$ Davie, 'Editorial', PN Review, 2 (1978) http://www.pnreview.co.uk/cgibin/scribe?item_id=7781 accessed 4 February 2018.

${ }^{29}$ Qtd. in William H. Prichard, 'Donald Davie, The Movement and Modernism', Leader (ed.), The Movement Reconsidered, 230.

${ }^{30}$ Davie, 'Remembering the Movement', The Poet in the Imaginary Museum, ed. Barry Alpert (Manchester, 1977), 72-5.

${ }^{31}$ Herd, 'Dislocating Country', 502. Note the absence of reference to Davie's sustained engagement with Anglo-American modernism, particularly the international sensibilities of Pound.

${ }^{32}$ Herd, 'Dislocating Country', 504.

${ }^{33}$ Davie, Thomas Hardy and British Poetry (London, 1973), 126-7.

${ }^{34}$ Qtd. in Davie, 'Review', Old Masters (Manchester, 1993), 8.

${ }^{35}$ Davie, 'Review', 8.

${ }^{36}$ Davie, Purity of Diction in English Verse and Articulate Energy (Manchester, 2006), 16.

${ }^{37}$ Davie, Purity of Diction, 91-3. 
${ }^{38}$ Qtd. in Clive Wilmer, 'Donald Davie and Thom Gunn', Leader (ed.), The Movement Reconsidered, 214.

${ }^{39}$ Davie, Purity of Diction, $\mathrm{x}$.

${ }^{40}$ Davie, Purity of Diction, 16. For a discussion of Davie's thesis in the broader context of post-war British poetry, see Michael Thurston and Nigel Alderman, Reading Postwar British and Irish Poetry (Oxford, 2014), 231.

${ }^{41}$ Davie, Purity of Diction, 165.

42 Noa Halvey, 'Pasternak and Donald Davie', Common Knowledge, 23 (2017), 404-39, 406. As Halvey shows, Pasternak was particularly vital for Davie's use of translation in Essex Poems.

${ }^{43}$ Davie, 'Eliot in One Poet's Life', Modernist Essays, 157-8.

${ }^{44}$ Eliot, 'Civilization: The Nature of Cultural Relations', 18 March 1943, qtd. in C. Behr, T.

S. Eliot: A Chronology of his Life and Works (Basingstoke, 1983), 58.

${ }^{45}$ See Eliot's Christianity and Culture: The Idea of a Christian Society and Notes towards the Definition of Culture (New York, 1949).

${ }^{46}$ Davie, 'Anglican Eliot', Modernist Essays, 159.

${ }^{47}$ Davie, 'Anglican Eliot', 159. Davie remained sensitive to the distinction between 'English' and 'British' and to what this entails when the 'dominant British culture, English,' risks 'distort[ing] exponents of the other British cultures' (TtC, 91).

${ }^{48}$ Eliot, 'East Coker', The Poems of T. S. Eliot: Volume I, ed. Christopher Ricks and Jim McCue (London, 2016), 191.

${ }^{49}$ Davie, 'Anglican Eliot', 160.

${ }^{50}$ Davie, 'Anglican Eliot', 160.

${ }^{51}$ Qtd. in Leader, 'Movement Fiction and Englishness', 1.

52 Auden, The Age of Anxiety (London, 1948), 11.

${ }^{53}$ W. H. Auden, 'The Shield of Achilles', Selected Poems (London, 1979), 198.

${ }^{54}$ Esty, A Shrinking Island, 4.

55 'commonwealth, n.' OED Online, oed.com/view/Entry/37261. Accessed 12 July 2018.

56 John Wain, Anthology of Modern Poetry (London, 1963), 35 [emphasis retained].

57 Auden, 'The Shield of Achilles', Selected Poems, 198.

${ }^{58}$ For a sustained engagement with Davie's modernist debts, see Julian Stannard's The Poetic Achievements of Donald Davie and Charles Tomlinson: Expanding Vision, Voice and Rhythm in Late Twentieth-Century English Poetry (Lewiston, NY, 2010).

${ }^{59}$ Davie, 'England as Poetic Subject', Poetry, 100 (1962), 121-3, 121.

${ }^{60}$ Echoing The Waste Land, the poem is even accompanied by a list of 'sources' given by Davie in his notes for his 1972 Collected Poems.

${ }^{61}$ Davie, 'Larkin's Politics, and Tomlinson's', Under Briggflatts (Manchester, 1989), 61.

62 As Clive Wilmer puts it, Davie's 'intermittent fury with his homeland was an anger that comes of love' ('Donald Davie and Thom Gunn', 207). 
${ }^{63}$ Larkin, 'Naturally the Foundation Will Bear Your Expenses', Collected Poems, 84.

${ }^{64}$ Davie, 'Larkin's Politics', 61.

65 '[T] 1951 General Census gave the non-white population of [Britain] at about 75,000 [...] by the 1961 census the figure had quadrupled to over 330,000' (Thurston and Alderman, Reading Postwar British and Irish Poetry, 22).

66 The poem's ambiguity on this point anticipates Davie's at times problematic late essay 'Poet: Patriot: Interpreter', written for a special issue of Critical Inquiry on the subject of postcolonial critical methods $(9: 2,1982,27-43)$. For a discussion of this in the context of Seamus Heaney's 'The Flight Path', dedicated 'for Donald Davie' when published in $P N$ Review in 1992, see Michael R. Molino, 'Charting an Uncertain Flight Path: Irish Writers and the Question of Nation, Identity, and Literature', The Comparatist, 20 (1996), 41-9.

${ }^{67}$ Ezra Pound, 'Canto LXXX', Selected Poems 1908-1959 (London, 1975), 178.

${ }^{68}$ In 'Ezra Pound Abandons the English', Davie places 'Canto LXXX' in its biographical contexts. Poetry Nation, 4 (1975) <http://www.pnreview.co.uk/cgi-bin/scribe?item_id=4140> accessed: 5 February 2018.

${ }^{69}$ Davie, 'Ezra Pound Abandons the English'.

${ }^{70}$ Barbara Everett, 'Poetry and Christianity,' London Review of Books, 4 (1982) https://www.lrb.co.uk/v04/n02/barbara-everett/poetry-and-christianity accessed: 4 February 2018.

${ }^{71}$ Gervais, Literary Englands, 30.

72 A. E. Housman, 'Into my heart an air that kills', A Shropshire Lad (London, 2010), 51.

${ }^{73}$ Everett, 'Poetry and Christianity'.

74 Larkin, 'Going Going', 134.

75 Journal entry, 1980, qtd. in A Travelling Man (Manchester, 2003), xiii.

${ }^{76}$ George Orwell, England Your England (London, 2017), 23.

77 Davie, 'Editorial', PN Review, 2 (1978) http://www.pnreview.co.uk/cgibin/scribe?item_id=7781 accessed 4 February 2018. 